\title{
Fishing Arctic Foxes Alopex lagopus on a rocky island in West Greenland
}

\author{
SUSSIE MØLLER NIELSEN
}

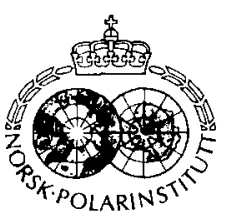

Nielsen. S. M. 1991: Fishing Arctic Foxes Alopex lagopus on a rocky island in West Greenland. Polar Research 9(2), 211-213.

On a small barren island in Disko Bay, West Greenland, 195 hours were spent observing Arctic Foxes at their den and the nearby coast. Their main food was found to be live, caught fish, and the activity of the foxes was correlated with the tidal height.

S. M. Nielsen, Arctic Station, University of Copenhagen. DK-3953 Godhavn, Greenland.

\section{Introduction}

Although previously published works contain brief and desultory remarks indicating that the Arctic Fox Alopex lagopus is capable of catching live fish (Cranz 1765; Fabricius 1780; Sæmundsson 1939; Pedersen 1959), only Kaikusalo (1971) describes actually having seen a fox unsuccessfully trying to catch a fish. Hence, no detailed description of fishing Arctic Foxes has been given to date.

This paper aims to describe how Arctic Foxes catch live fish, how efficient they are, and to what extent they can rely on this food source.

\section{Study area}

The study took place on a $2 \mathrm{~km}^{2}$ island $(0-70 \mathrm{~m}$ a.s.h.) that belongs to the archipelagos of Kronprinsens Ejland, Disko Bay $(69 \mathrm{~N} 53 \mathrm{~W})$. West Greenland. The island is formed by precambrian rocks, and except for two small beaches the coastline $(9 \mathrm{~km})$ is rocky $(1 / 3$ steep cliffs $)$. The distance to the nearest island is $1.8 \mathrm{~km}$. At low tide several rock pools with rich seaweed vegetation (mainly Fucus disticus) are uncovered. The tidal fluctuation varied during June and July from $0.1 \mathrm{~m}$ to $2.7 \mathrm{~m}$ (mean $0.8 \mathrm{~m}$ ). The island is sparsely vegetated by dwarf shrub heath, mainly Crowberry Empetrum hermaphroditum. Herb and marsh vegetation is found in narrow zones around ponds. Terrestrial animal life is poor (see also Porsild \& Ostermann 1921). No signs of other mammals were found, and the only breeding bird species observed was the Snow Bunting Plectrophenax nivalis. Along the coast, however, several species of sea birds were foraging and some were seen resting on the cliffs almost daily.

\section{Materials and methods}

The observations were initiated 22 June 1990 when a family of dark phased ("blue") foxes was located. At the time the family consisted of 2 adults (nursing female and male) and 6 cubs ( $4-5$ weeks old). The two adults were easily identified by distinct fur characteristics, and sex-determination of the male was made at close hand. The family was still intact on $30 \mathrm{July}$ when the last observations were made. Within this period the island was visited for ten 24-hour periods. In total, 195 hours were spent observing both the den and about $200 \mathrm{~m}$ coastline with rock pools. The observations were made from cliffs at about $10 \mathrm{~m}$ a.s.1., $70 \mathrm{~m}$ from the den, and $100 \mathrm{~m}$ from the coast. The equipment consisted of binoculars $(10 \times 50)$ and a watch. The time (to the nearest minute) was recorded when an adult fox began to forage between the coastal rocks and the moment it stopped or went out of sight. Also recorded were the moment when a fish was caught and when an item was delivered to the cubs. Fish and other items were identified when possible. In addition, sleeping sequences were noted; the time when an adult went to sleep as well as the length of time it slept were recorded. The results are related to tide tables for Kronprinsens Ejland 1990.

\section{Results}

At least one adult fox was in focus for 39 hours and 14 minutes ( $20 \%$ of the observation time). The adults were in sight simultaneously for 39 minutes, so the total observation time of individual adult foxes was 39 hours and 53 minutes (the male was observed for 24 hours and 7 minutes, the female for 15 hours and 32 minutes, and there were 14 minutes when the sex could not be recognized). Altogether the two adults foraged at the coast for 6 hours and 59 minutes (range 1-37 minutes) distributed over 32 sequences. Within this time a minimum of 25 fish were caught (mean 17 minutes per catch and 0.8 fish per sequence). The male caught 9 fish in 4 hours and 13 minutes (13 sequences; mean 28 minutes per catch and 0.7 fish per sequence). The female caught 16 fish in 2 hours and 46 minutes (19 sequences; mean 10 minutes per catch and 0.8 fish per sequence). One morning when conditions for fishing may have been especially favourable, the female caught 6 fish in 28 minutes. 

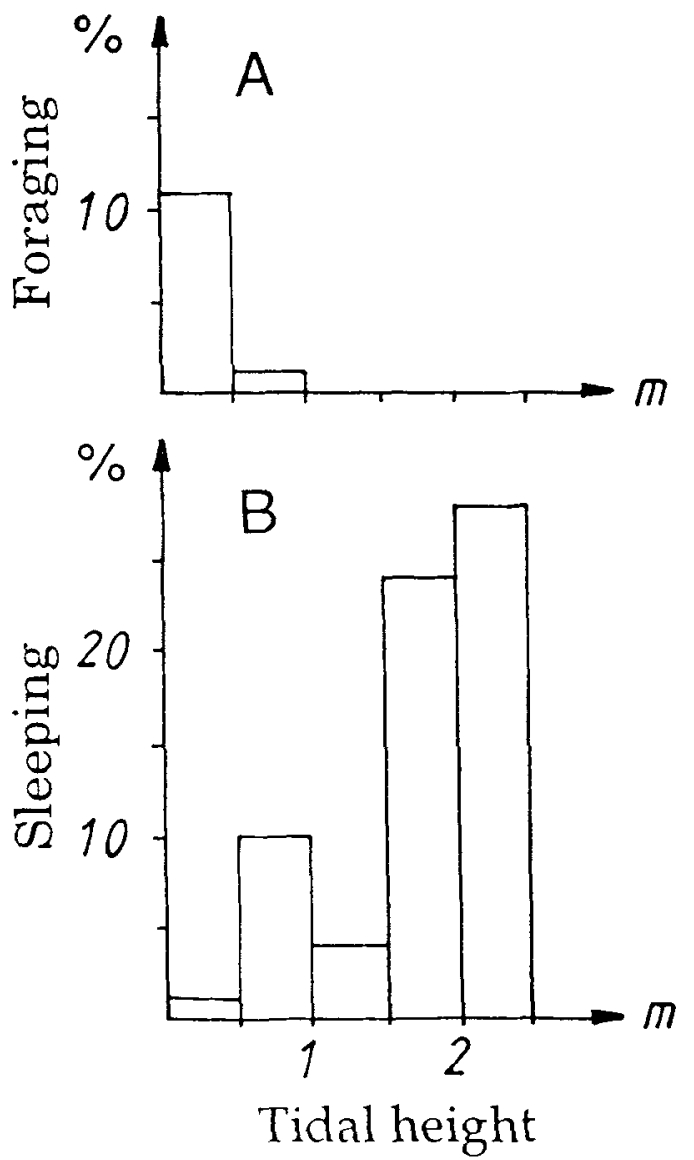

Fig. 1. The proportion ( $\%$ ) of the observation time the adult foxes spent foraging at the coast (A) and sleeping (B) in relation to the tidal height. Observation time in minutes: $3140(0 .(1)$ $(0.5 \mathrm{~m}): 4055(0.5-1.0 \mathrm{~m}): 3.370(1.0-1.5 \mathrm{~m}): 835(1.5-2.0 \mathrm{~m})$ and $300)(2.1-2.5 \mathrm{~m})$.

The foxes were seen searching for food at the coast only when the tide was below $1 \mathrm{~m}$. and the amount of time spent foraging was inversely proportional to the tidal height (Fig. 1A). On the contraty. $84^{t}$ of the time spent slecping (always in the cliffs above the den) occurred when the tide was above $1 \mathrm{~m}$ (Fig. 1B). The adult foxes were observed slecping for a total of 14 hours and 4 minutes (the male was observed sleeping for a total of 8 hours and 55 minutes and the female for 5 hours and 9 minutes). The mean slecping time was 34 minutes (range $4-105 . n=25$ ).

When the foxes travelled along the coast they foraged either by turning seaweed with a front paw and gleaning Amphipodes from the algac, or by searching for fish in cracks and rock pools on their way.

When fishing, the fox would stand with its hindquarters on the edge of a pool. the tail pointing vertically upwards. and with most of its head and forepart hidden between rocks and seawed. During the catch, the fox twisted its tail from side to
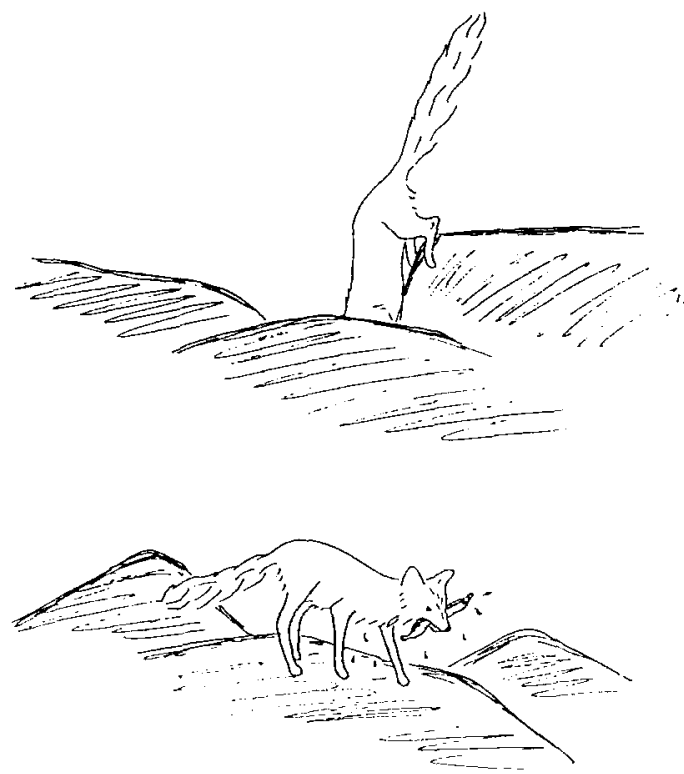

Fig. 2. Adult fox catching live tish in a rock pool (ficld sketch).

side to keep its balance. These fishing scenarios lasted only for a few seconds. after which the fox often appeared with a wrig gling fish in its mouth (Fig. 2). The fox cither delivered the fish (often still wriggling) to the cubs, ate it on the way back to the den, or left it on a rock while continuing to fish. Five times a fox was seen depositing a fish between rocks or in a small hole (10 to $15 \mathrm{~cm}$ deep) in the nearest surroundings of the den. These holes were dug with the front paws. and after depositing the prey the fox covered the holes by pushing and patting the earth down with its nose. The foxes were not seen entering the water to catch fish; they were usually wet only on the head and forcpart when they returned from fishing. They often spent some time drying their coats by rubbing themselves against the vegetation. On one occasion the male returned to the den soaking wet, with a Lump-sucker Cyclopterus lumpus, indicating that it might have been necessary for him to enter the water to catch the large fish. After delivering the fish to the cubs. he shook the water off his coat and rubbed against the vegetation. Only once was a fox seen swimming between the sherries of the coast (a distance of about $2 \mathrm{~m}$ ), but I have seen Arctic Foxes swim across a $10 \mathrm{~m}$ wide river on several occasions in another location. They are steady but not fast swimmers. lying fairly high in the water (head and back dry and the tail floating behind), partly held up by the dense and puffy coat. Immediately after swimming. the fox shakes the water from the coat, often while it is still moving on.

Of 40 items delivered to the cubs ( 23 fish. 1 Snow Bunting. 1 wing of a Raven Corvus corax and 15 not identified), most were delivered at low tide $(<1 \mathrm{~m})$ and most items delivered at high tide had been dug up from prey deposits near the den (Table 1).

In all, 36 fish were seen caught, delivered to the cubs, or both: 19 Banded Gunnels Pholis fasciatus, 2 Lump-suckers, 1 Father-lasher Myoxocephalus sp. and 14 not determined. 
Table 1. Total observation time at low tide $(<1 \mathrm{~m})$ and high tide $(>1 \mathrm{~m})$, the number and frequency of items delivered to the cubs and of items dug up and delivered.

\begin{tabular}{lcccc}
\hline & $\begin{array}{c}\text { Obs. time in } \\
\text { minutes }(\%)\end{array}$ & Items delivered & No./hour & $\begin{array}{l}\text { Items dug up and } \\
\text { delivered }(\% \text { of } \\
\text { items delivered) }\end{array}$ \\
\hline Tidal height: & & No. & & $3(9)$ \\
$<1 \mathrm{~m}$ & $7195(61)$ & 32 & $0.3 \rightarrow$ & $5(63)$ \\
$>1 \mathrm{~m}$ & $4505(39)$ & 8 & $0.1 \rightarrow$ & $8(20)$ \\
Total & $11700(100)$ & 40 & $0.2 \rightarrow$ & \\
\hline
\end{tabular}

\section{Discussion}

The present observations document that Arctic Foxes are able to catch live fish with a high degree of success. They were not seen, however, alluring the fish with a paw as described by Cranz (1765) and Fabricius (1780).

That hunting took place mainly at low tide and that live. caught fish comprised the most important food source for the fox family during the observation period are supported by the following facts: 1) Prey delivered to the cubs consisted primarily of fish; 2) Prey were delivered mainly at low tide; 3) Most prey delivered at high tide were dug up from deposits; 4) The bulk of the sleeping time occurred during high tide.

A number of wings of sea birds found at the den had probably been taken from a nearby hut where several leftovers from hunters lay scattered, including wings of sea birds of the same species as found at the den (the hut was not in use during the study period).

Arctic Foxes inhabit several small islands in the Disko Bay, and fishing foxes may be a common, but overlooked. phenomenon. In Iceland remains of Lump-sucker is commonly found at fox dens (Hersteinsson 1984).

The present island is much smaller than Arctic Fox home ranges measured by radiotracking elsewhere (more than $8 \mathrm{~km}^{2}$ ) (Eberhardt et al. 1982; Hersteinsson \& Macdonald 1982; Birks \& Penford 1990). A rocky coastline may therefore be a richer habitat for Arctic Foxes than both inland and beach areas due to the foxcs' ability to catch live fish with high efficiency. This may be an important new aspect in the understanding of the distribution and ecology of the Arctic Fox.

Acknowledgements. - For company and assistance in the ficld I want to thank T. B. Berg, A. Caulfield and O. Frimer. Special thanks go to A. Jensen for her efforts and participation in the ficld. I am also gratcful to P. Provencal for translating parts of Fauna Groenlandica (Fabricius 1780) from Latin to Danish, and to H. Walhovd and L. Albright for various help.
The manuscript benefitted from criticism and suggestions from $O$. Frimer and $P$. Mølgaard and was kindly read by $B$. Muus. The study is supported by grants from the Commission for Scientific Research in Greenland and the Carlsberg Foundation.

\section{References}

Birks. J. D. S. \& Penford, N. 1990: Observations on the ecology of arctic foxes Alopex lagopus in Eqalummiut Nunaat. West Greenland. Meddr. Gronland. Bioscience $32.26 \mathrm{pp}$.

Cranz, D. 1765: Historie von Grönland. Leipzig.

Eberhardt, L. E., Hanson, W. C., Bengtson, J. L., Garrott, R. A. \& Hanson, E. E. 1982: Arctic Fox home range charac1eristics in an oil-development area. J. Wildl. Manage. 46. 183-190.

Fabricius, O. 1780: Fauna Groenlandica. Hafnia \& Lipsiac.

Hersteinsson, P. 1984: Behavioural Ecology of the Arctic fox Alopex lagopus in Iceland. Unpubl. Ph.D. thesis. University of Oxford.

Hersteinsson, P. \& Macdonald, D. W. 1982: Some Comparisons Between Red and Arctic Foxes. Vulpes vulpes and Alopex lagopus. as Revealed by Radio Tracking. Symp. Zool. Soc. Lond. 49, 259-289.

Kaikusalo, A. 1971: Om fjälrävens (Alopex lagopus) forplantning i nordvästra Enontkis i Finska Lapmarken. Suomen Rista. 23, 7-16. (Translation by $\mathrm{T}$, Forsgren in Finsk Viltforskning 1974, 149-156).

Pedersen. A. 1959: Der Eisfuchs Alopex lagopus Linné. Zicmens Verlag, Wittenberg-Lutherstadt.

Porsild, M. P. \& Ostermann, H. 1921: Godhavn distrikt. Meddr. Grønland 1. 270-341.

Sæmundsson, B. 1939: Mammalia. Pp. 1-38 in Frederiksson, A. \& Tuxen, S. L. (cds.): The Zoology of Iceland IV. Vol. 76. Copenhagen and Reykjavik. 
